\title{
The feto-placental glucose steal phenomenon is a major cause of maternal metabolic adaptation during late pregnancy in the rat
}

\author{
C.J.Nolan, J. Proietto \\ University of Melbourne, Department of Medicine, Royal Melbourne Hospital, Victoria, Australia
}

\begin{abstract}
Summary The aim of this study was to determine the extent to which a feto-placental glucose steal phenomenon contributes to the process of maternal metabolic adaptation to late pregnancy. Glucose metabolism was studied in virgin control, pregnant rats and virgin rats with a phlorizin-induced model of the feto-placental glucose steal phenomenon. Whole body glucose kinetics and glucose uptake into individual tissues were measured in anaesthetised rats basally and during hyperinsulinaemic euglycaemic clamps. The basal glucose metabolism of the pregnant rats was closely mimicked by the phlorizin-treated rats. Basal plasma glucose was $39 \%$ and $38 \%$ lower ( $p<0.0001$ for both); hepatic glucose production was $21 \%$ and $26 \%$ higher ( $p<0.05$ for both); and plasma glucose clearance was $109 \%$ and $104 \%$ higher ( $p<0.0001$ for both) in the pregnant and phlorizin-treated rats, respectively, compared to the
\end{abstract}

control rats. Basal glucose uptake into peripheral tissues was lower in both the pregnant and phlorizintreated compared to the control rats, being most evident in heart $(p<0.01$ for both) and brown adipose tissue $(p<0.001$ for both). In the clamp studies, impairment of glucose uptake into skeletal muscle was observed in both the pregnant and phlorizin-treated rats compared to the control rats. In conclusion, the feto-placental glucose steal phenomenon is a major contributing factor to postabsorptive glucose metabolism in late pregnancy. This phenomenon also contributes to the impairment of maternal insulin-stimulated peripheral glucose uptake. [Diabetologia (1994) 37: 976-984]

Key words Phlorizin, glucose kinetics, hyperinsulinaemic euglycaemic clamp, insulin, non-esterified fatty acid.
The developing feto-placental unit demands a progressively increasing nutrient supply through the later stages of pregnancy. Gestational hormones are clearly involved in adapting maternal metabolism so as to ensure this nutrient supply. Early to midpregnancy is a period of maternal energy storage through

Received: 27 January 1994

and in revised form: 4May 1994

Corresponding author: Dr. C.J.Nolan, University of Melbourne, Department of Medicine, Royal Melbourne Hospital, Melbourne, Victoria 3050, Australia

Abbreviations: NEFA, Non-esterified fatty acid; HGP, hepatic glucose production; GCR, glucose clearance rate; Ra, glucose appearance rate; $\mathrm{Rd}$, glucose disposal rate; $\mathrm{Ru}$, glucose uptake rate. a process of "facilitated anabolism" $[1,2]$. Undoubtedly important to this process are the hormones oestrogen [3-5], progesterone $[4,5]$ and placental lactogen [6] which augment pancreatic islet beta-cell responsiveness and increase insulin levels. In contrast, maternal metabolism late in pregnancy is characterised by a process of "accelerated starvation" such that the increased maternal energy stores can be rapidly mobilised during postabsorptive periods. Placental lactogen [7], prolactin [8], progesterone [9] and cortisol [2] have been implicated in producing a physiological insulin resistance which has at least a permissive role in the process of "accelerated starvation". It is unknown, however, the extent to which a feto-placental steal of maternal nutrients, including glucose, influences maternal metabolism in late pregnancy. It would seem logical to expect that an obli- 
gate maternal glucose loss to the developing conceptus, which we have termed "the feto-placental glucose steal phenomenon", would promote the metabolic milieu of "accelerated starvation". Further to this, glucose deprivation in non-pregnant individuals, whether caused by diets low in carbohydrate $[10,11]$ or by starvation $[12,13]$, has been shown to produce glucose intolerance and insulin resistance. It may be that through similar mechanisms the feto-placental glucose steal phenomenon also contributes to the insulin resistance of late pregnancy.

Phlorizin infused into rats causes marked urinary glucose loss [14]. In the present study we have used phlorizin-treated virgin rats to model the feto-placental glucose steal phenomenon of pregnancy. Whole body glucose kinetics and glucose uptake into individual peripheral tissues were studied in control virgin, phlorizin-treated virgin and pregnant rats under both fasting and hyperinsulinaemic euglycaemic clamp conditions. Initial validation experiments were performed on functionally anephric rats to exclude a direct effect of phlorizin on glucose metabolism.

\section{Materials and methods}

Experimental animals. Female, age-matched (100 days) Sprague Dawley rats (Monash University Animal Facility, Clayton, Vic., Australia) were used. All animals were housed in a temperature controlled environment $\left(22^{\circ} \mathrm{C}\right)$ and were subject to controlled lighting ( $12 \mathrm{~h}$ dark $/ 12 \mathrm{~h}$ light). Animals had free access to water and standard laboratory chow (Barastoc, $\mathrm{Pa}$ kenham, Vic., Australia).

Validation experiments. To validate the use of phlorizin, we studied two groups of functionally anephric rats: control nephrectomised and phlorizin-treated nephrectomised. Following an overnight fast the rats were anaesthetised with $60 \mathrm{mg}$ / $\mathrm{kg}$ intraperitoneal pentobarbitone (Boehringer Ingelheim, Artarmon, NSW, Australia). Both renal arteries were tied through a midline laparotomy incision. The incision was then covered with gauze soaked in warmed normal saline $(0.9 \%$ $\mathrm{NaCl})$. Silastic cannulas (0.012 in. internal diameter, Dow Corning Australia, Hawthorn, Vic., Australia) were inserted into the right jugular vein (one cannula for basal studies, two cannulas for insulin clamp studies) for infusions and the left carotid artery for blood sampling. A tracheostomy was also performed to assist maintenance of the airway. These surgical procedures were followed by a 30 -min rest period. Body temperature was maintained at $38^{\circ} \mathrm{C}$ using a heat lamp and a rectal temperature probe (Tele-thermometer, Yellow Springs Instrument Company, Yellow Springs, Ohio, USA). Anaesthesia was maintained by intermittent doses $(15 \mathrm{mg} / \mathrm{kg})$ of intraperitoneal pentobarbitone as required. Infusates were prepared as follows. Phlorizin (Sigma Chemical Co., St. Louis, Mo., USA) initially dissolved in propylene glycol (Sigma Chemical Co.) $49 \mathrm{mg} / \mathrm{ml}$ ) (phlorizin-treated nephrectomised rats) or propylene glycol only (control nephrectomised rats) were diluted in Haemaccel (polygeline 35 g/l, Behring Institut, Marburg, Germany) and $0.9 \% \mathrm{NaCl}$ in a ratio of $2: 1: 17$. Rats received a primed $(0.25 \mathrm{ml}$ in $5 \mathrm{~min})$ continuous infusion $(0.01 \mathrm{ml} / \mathrm{min})$ of the phlorizin or control infusate via a jugular vein catheter from time 0 for the duration of the experiment. Measurements of whole body glucose kinetics and individual tissue glucose uptake indices under basal and hyperinsulinaemic euglycaemic conditions were performed as described below. The phlorizin infusate, if given to intact rats, acutely induced marked glycosuria $\left(21.5 \pm 2.2 \mu \mathrm{mol} \cdot \mathrm{kg}^{-1} \cdot \mathrm{min}^{-1}\right)$, thus confirming it's bioavailability when administered in this way.

Study experiments. Three groups of rats were studied: control virgin; phlorizin-treated virgin and pregnant. The phlorizintreated rats received phlorizin dissolved in propylene glycol at a rate of $0.075 \mathrm{~g} /$ day via subcutaneously situated osmotic pumps (Model 2Ml1, Alza Corporation, Palo Alto, Calif., USA). Osmotic pumps were inserted into all animals (control and pregnant rats had propylene glycol vehicle loaded pumps only) under intraperitoneal pentobarbitone anaesthesia 7 days prior to metabolic assessment. The rats were fasted from 18.00 hours on day 6 and at 08.00 hours on day 7 were anaesthetised, cannulated and rested for $30 \mathrm{~min}$, as described above, prior to the commencement of metabolic assessment. The pregnant rats were at 19 days gestation on day 7 . Measurements of whole body glucose kinetics, NEFA levels and individual tissue glucose uptake indices under basal and hyperinsulinaemic euglycaemic conditions were performed as described below.

Measurement of whole body glucose kinetics. A primed (5 min priming dose of $6.25 \mu \mathrm{Ci} / \mathrm{kg})$ continuous infusion $(0.25 \mu \mathrm{Ci}$ $\cdot \mathrm{kg}^{-1} \cdot \min ^{-1}$ ) of $\left[6{ }^{3} \mathrm{H}\right]$ glucose (New England Nuclear, Boston, Mass., USA) was commenced at time 0 min in all studies. A primed $(5 \times$ continuous rate for $5 \mathrm{~min})$ continuous infusion of insulin (Actrapid, CSL-Novo, North Rocks, NSW, Australia) at either 0.0 (basal studies), 3.0 (low-dose clamp) or $12.0 \mathrm{mU} \cdot \mathrm{kg}^{-1} \cdot \mathrm{min}^{-1}$ (high-dose clamp) was also commenced at time $0 \mathrm{~min}$. As the volume of distribution of maternal insulin does not include the fetus, $20 \%$ lower insulin infusion rates of 2.4 (low-dose clamp) and $9.6 \mathrm{mU} \cdot \mathrm{kg}^{-1} \cdot \mathrm{min}^{-1}$ (high-dose clamp) were used in the pregnant rats. Basal and low-dose clamp studies only were performed in the validation experiments. The $\left[6^{3} \mathrm{H}\right]$ glucose and insulin were infused together as additives to the phlorizin or control infusates in the validation experiments; whereas they were infused together within a solution of $0.9 \% \mathrm{NaCl}$ and Haemaccel (ratio 9:1) in the study experiments. During the clamp studies blood glucose was measured every $10 \mathrm{~min}$ and accordingly a variable glucose infusion $(10 \%$ glucose in low-dose clamp and $20 \%$ glucose in high-dose clamp studies) was used to maintain plasma euglycaemia at $6.0 \mathrm{mmol} / 1$ in the validation experiments and $5.0 \mathrm{mmol} / 1$ in the study experiments. To avoid large fluctuations in plasma glucose specific activity 3.5 and $7.0 \mu \mathrm{Ci} / \mathrm{ml}$ $\left[6^{3} \mathrm{H}\right]$ glucose was added to the $10 \%$ and $20 \%$ glucose infusates, respectively. Steady-state plasma glucose and exogenous glucose infusion rates were achieved in the clamp studies by 70 to $100 \mathrm{~min}$. Three arterial blood samples $(300 \mu \mathrm{l})$ spaced at 5 -min intervals were taken from time $70 \mathrm{~min}$ in the basal studies and from time 100 to $130 \mathrm{~min}$ in the clamp studies for plasma glucose, insulin and $\left[6{ }^{3} \mathrm{H}\right]$ glucose specific activity determinations. The erythrocytes from all blood samples were resuspended in $0.9 \% \mathrm{NaCl}$ and given back to the animal periodically through the experiments. The urinary bladder was emptied at time 0 min by suprapubic pressure. At the end, urine was collected from the bladder by needle aspiration for determination of the rate of urinary glucose loss. At the end of the experiments timed collections of the infusates were obtained for accurate determination of the $\left[6^{3} \mathrm{H}\right]$ glucose infusion and exogenous cold glucose infusion rates. 
Measurement of NEFA levels. Heparinised $0.9 \% \mathrm{NaCl}$ was avoided until after blood samples were taken for NEFA measurement. In both basal and clamp studies blood samples $(300 \mu \mathrm{l})$ were taken at the 20 and $50 \mathrm{~min}$ time points for measurement of serum NEFA levels.

Measurement of individual tissue glucose utilisation indices. A modification of the labelled 2-deoxyglucose technique described by Kraegen et al. [15] was used. The basal and clamp studies were continued following the blood samples for measurement of whole body glucose kinetics. A bolus of $\left[{ }^{14} \mathrm{C}\right] 2$-deoxyglucose $(100 \mu \mathrm{Ci}$, New England Nuclear, Boston, Mass., USA) was given intravenously and blood samples $(300 \mu \mathrm{l})$ were taken $2,5,10,15,20,30$ and 45 min later for measurement of plasma glucose and the time course of $\left[{ }^{14} \mathrm{C}\right] 2$-deoxyglucose disappearance. After the 45-min blood sample, the rats were immediately killed with an intravenous overdose of pentobarbitone and samples of brain, white and brown adipose tissue, diaphragm, heart, soleus, red and white gastrocnemius and red and white quadriceps, and in pregnant rats, placenta and fetus were rapidly removed and frozen in liquid nitrogen for subsequent analysis.

Analytical methods. Glucose levels in blood, plasma and urine were measured using a 23 AM YSI Glucose Analyser (Yellow Springs Instrument Company, Yellow Springs, Ohio, USA). Plasma insulin was measured using a double antibody method (Phadeseph Pharmacia, Uppsala, Sweden). Serum NEFA were measured using an enzymatic colorimetric commercial kit (Wako Pure Chemical Industries, Osaka, Japan). To measure plasma tracer concentrations, $50 \mu \mathrm{l}$ of plasma was de-proteinised with an equal volume of saturated $\mathrm{Ba}(\mathrm{OH})_{2}$ and $5.5 \% \mathrm{ZnSO}_{4}$. The supernatant of the samples for specific activity of glucose were passed through an anion exchange resin column (Dowex- $2 \times 8,200-400$ mesh, $\mathrm{Cl}$ form, Bio-Rad Laboratories, Richmond, Calif., USA) to remove labelled charged metabolites (lactate/pyruvate). The columns were washed with water and the samples were dried $\left(60^{\circ} \mathrm{C}\right)$ to remove tritiated water. All samples were then resuspended in $4 \mathrm{ml}$ water and after addition of $8 \mathrm{ml}$ scintillation fluid (Readyvalue, Beckman, Palo Alto, Calif., USA) were counted in a beta-scintillation counter (Beckman Instruments, Irvine, Calif., USA). The timed [6$\left.{ }^{3} \mathrm{H}\right]$ glucose infusate collections were also dried, resuspended and counted as above. $\left[{ }^{14} \mathrm{C}\right] 2$-deoxyglucose dpm were counted using a quench corrected (external standard) double isotope programme. Tissues (up to $250 \mathrm{mg}$ ) for measurement of $\left[{ }^{14} \mathrm{C}\right] 2$-deoxyglucose uptake were digested in $1 \mathrm{ml} 1 \mathrm{~mol} / \mathrm{l}$ $\mathrm{NaOH}$. Placentas $(\times 3)$ and fetuses $(\times 2)$ were digested, respectively, in $2 \mathrm{ml}$ and $10 \mathrm{ml}$ of $1 \mathrm{~mol} / 1 \mathrm{NaOH}$. The digestion was performed over $90 \mathrm{~min}$ in a shaking water bath set at $60^{\circ} \mathrm{C}$. After digestion, the maternal tissue samples were made up to $2 \mathrm{ml}$ with $1 \mathrm{~mol} / \mathrm{l} \mathrm{NaOH}$ and then neutralised with $2 \mathrm{ml}$ of $1 \mathrm{~mol} / \mathrm{l} \mathrm{HCL}$. The placental and fetal digestates were made up to $5 \mathrm{ml}$ and $20 \mathrm{ml}$ with $1 \mathrm{~mol} / 1 \mathrm{NaOH}$, respectively, and neutralised with equal volumes of $1 \mathrm{~mol} / 1 \mathrm{HCL}$. Two separate $1-\mathrm{ml}$ aliquots of the digestates were taken. Two $\mathrm{ml} \mathrm{HClO}_{4}(6 \%$ weight/volume $)$ was added to the first aliquot and $1 \mathrm{ml} \mathrm{Ba}(\mathrm{OH})_{2}$ followed by $1 \mathrm{ml} \mathrm{ZnSO}_{4}$ was added to the second aliquot. After centrifugation the $\mathrm{HClO}_{4}$ supernatants contained $\left[{ }^{14} \mathrm{C}\right] 2$-deoxyglucose plus $\left[{ }^{14} \mathrm{C}\right] 2$-deoxyglucose 6-phosphate while the $\mathrm{Ba}(\mathrm{OH})_{2} / \mathrm{ZnSO}_{4}$ supernatants contained only $\left[{ }^{14} \mathrm{C}\right] 2$-deoxyglucose. Two $\mathrm{ml}$ of each supernatant was made up to $4 \mathrm{ml}$ with water to which $8 \mathrm{ml}$ of scintillation fluid was added. The ${ }^{14} \mathrm{C}$ radioactivity was counted using the dual label programme on the beta-scintillation counter.
Calculations. In steady state, the total body glucose appearance rate $(\mathrm{Ra})$ is equal to the $\left[6-{ }^{3} \mathrm{H}\right]$ glucose tracer infusion rate $(\mathrm{dpm} / \mathrm{min})$ divided by the plasma glucose specific activity (dpm/ $/ \mathrm{mol}$ ). After an overnight fast, the Ra is equal to the hepatic glucose production rate (HGP). When blood glucose is constant the total body glucose disposal rate $(\mathrm{Rd})$ is equal to $\mathrm{Ra}$. During the hyperinsulinaemic clamp studies, the $\mathrm{Ra}$ is the sum of the HGP and the rate of infused unlabelled glucose. Thus, HGP is equal to the difference between the tracer-determined $\mathrm{Ra}$ and the directly measured glucose infusion rate. The total body glucose uptake rate $(\mathrm{Ru})$ equals the $\mathrm{Rd}$ minus the urinary glucose loss. The plasma glucose clearance rate (GCR) equals the $\mathrm{Rd}$ divided by the plasma glucose concentration. Glucose utilisation indices for individual tissues were calculated from the mean plasma glucose level $(\mu \mathrm{mol} / \mathrm{ml})$ following the bolus of $\left[{ }^{14} \mathrm{C}\right] 2$-deoxyglucose multiplied by the radioactivity of $\left[{ }^{14} \mathrm{C}\right] 2$-deoxyglucose 6-phosphate per mass of tissue $(\mathrm{dpm} / 100 \mathrm{~g})$ divided by the area under the plasma $\left[{ }^{14} \mathrm{C}\right] 2$-deoxyglucose radioactivity disappearance curve $\left(\mathrm{dpm} \cdot \mathrm{min} \cdot \mathrm{ml}^{-1}\right)$ [15]. The radioactivity of $\left[{ }^{14} \mathrm{C}\right] 2$-deoxyglucose 6-phosphate was calculated from the difference between the radioactivity measured in the $\mathrm{HClO}_{4}$ supernatant and the $\mathrm{Ba}(\mathrm{OH})_{2} / \mathrm{ZnsO}_{4}$ supernatant of the tissue digestates.

\section{Statistical analysis}

Results are presented as mean \pm SEM. Statistical significance of differences were assessed by the Student's unpaired $t$-test. In the study experiments, comparisons of means were made between the control and pregnant, and between the control and phlorizin rat groups only, unless otherwise stated. Statistical analysis was performed on logarithmically transformed values if the distribution of data was skewed.

\section{Results}

Validation experiments. The results of the validation experiments are shown in Table 1 . Under basal conditions plasma glucose and insulin, and whole body glucose kinetics were not different between the control nephrectomised and the phlorizin-treated nephrectomised rats. The basal glucose utilisation indices were not different in most tissues. Modest differences only were observed in brain (phlorizin-treated nephrectomised less than control nephrectomised) and white adipose tissue (phlorizin-treated nephrectomised greater than control nephrectomised). During the low-dose hyperinsulinaemic euglycaemic clamp studies, similar levels of plasma glucose were achieved; however, plasma insulin levels were slightly, but not significantly, higher in the phlorizin-treated nephrectomised rats. Whole body glucose kinetics were again not significantly different between the control nephrectomised and phlorizin-treated nephrectomised rats. The clamp tissue glucose uptake index measurements tended to be slightly higher ( 7 of 10 tissues) in the phlorizin-treated nephrectomised rats which was most probably an appropriate response to the slightly higher insulin levels in this group. These data demonstrate that, with the doses used, phlorizin does not directly alter glucose metabolism in tissues other than in the renal tubules. 
Table 1. Plasma glucose and insulin levels, HGP, Rd, GCR, and peripheral tissue glucose utilisation index measurements (GUI) during basal and low-dose hyperinsulinaemic euglycaemic clamp studies in control nephrectomised and phlorizin-treated nephrectomised rats

\begin{tabular}{|c|c|c|c|c|}
\hline & \multicolumn{2}{|c|}{ Control nephrectomised } & \multicolumn{2}{|c|}{ Phlorizin nephrectomised } \\
\hline & $\overline{\text { Basal }}$ & Clamp & Basal & Clamp \\
\hline Glucose (mmol/1) & $8.7 \pm 0.6$ & $8.3 \pm 0.3$ & $8.6 \pm 0.5$ & $7.9 \pm 0.6$ \\
\hline $\mathrm{HGP}\left(\mu \mathrm{mol} \cdot \mathrm{kg}^{-1} \cdot \mathrm{min}^{-1}\right)$ & $37 \pm 4$ & $43 \pm 4$ & $38 \pm 2$ & $33 \pm 6$ \\
\hline $\mathrm{Rd}\left(\mu \mathrm{mol} \cdot \mathrm{kg}^{-1} \cdot \min ^{-1}\right)$ & $37 \pm 4$ & $88 \pm 7$ & $38 \pm 2$ & $94 \pm 9$ \\
\hline $\mathrm{GCR}\left(\mathrm{ml} \cdot \mathrm{kg}^{-1} \cdot \mathrm{min}^{-1}\right)$ & $4.5 \pm 0.2$ & $10.5 \pm 0.6$ & $4.4 \pm 0.2$ & $11.9 \pm 0.9$ \\
\hline \multicolumn{5}{|l|}{ GUI $\left(\mu \mathrm{mol} \cdot 100 \mathrm{~g}^{-1} \cdot \min ^{-1}\right)$ in: } \\
\hline Brain & $18.6 \pm 1.2$ & $14.1 \pm 2.4$ & $14.5 \pm 0.9^{a}$ & $13.1 \pm 1.6$ \\
\hline White adipose tissue & $0.7 \pm 0.1$ & $1.8 \pm 0.5$ & $1.1 \pm 0.1^{\mathrm{a}}$ & $1.8 \pm 0.2$ \\
\hline Brown adipose tissue & $23 \pm 7$ & $89 \pm 27$ & $38 \pm 13$ & $115 \pm 33$ \\
\hline Diaphragm & $9.5 \pm 1.0$ & $15.5 \pm 1.9$ & $8.4 \pm 2.2$ & $24.0 \pm 2.7^{\mathrm{b}}$ \\
\hline Heart & $3.4 \pm 0.8$ & $23.9 \pm 2.7$ & $3.4 \pm 0.7$ & $25.2 \pm 7.1$ \\
\hline Soleus & $2.5 \pm 0.4$ & $8.3 \pm 1.3$ & $2.0 \pm 0.1$ & $8.1 \pm 0.9$ \\
\hline Red gastrocnemius & $2.6 \pm 0.3$ & $9.1 \pm 0.7$ & $2.5 \pm 0.3$ & $10.7 \pm 0.6$ \\
\hline White gastrocnemius & $1.1 \pm 0.1$ & $2.6 \pm 0.3$ & $1.4 \pm 0.2$ & $3.5 \pm 0.3$ \\
\hline Red quadriceps & $3.4 \pm 0.4$ & $9.6 \pm 1.0$ & $3.9 \pm 0.6$ & $13.4 \pm 1.4$ \\
\hline White quadriceps & $1.2 \pm 0.1$ & $3.6 \pm 0.5$ & $1.5 \pm 0.2$ & $4.9 \pm 0.6$ \\
\hline
\end{tabular}

Values are means \pm SEM of $4-6$ rats in each group. ${ }^{a} p<0.05$ vs control basal. ${ }^{b} p<0.05$ vs control clamp

Study experiments. The changes in rat weight from days 0 to 6 , and the rat weight on day 7 were not different between the control $(-1 \pm 1$ and $236 \pm 3 \mathrm{~g}$, respectively) and phlorizin-treated rats $(-2 \pm 2$ and $233 \pm 4 \mathrm{~g}$ ). As expected the pregnant rats had a significantly higher weight gain between days 0 and 6 ( $30 \pm 3 \mathrm{~g}, p<0.0001$ vs control) and were heavier on day 7 ( $290 \pm 6 \mathrm{~g}, p<0.0001$ vs control). Food consumption between days 0 and 6 was higher in the phlorizin-treated $(90 \pm 2 \mathrm{~g})$ and pregnant $(102 \pm 2 \mathrm{~g})$ compared to the control rats $(69 \pm 3 \mathrm{~g}, p<0.0001$ for both). Urinary glucose loss was negligible in control and pregnant rats (less than $0.1 \mu \mathrm{mol} \cdot \mathrm{kg}^{-1} \cdot \mathrm{min}^{-1}$ in all rats). In the phlorizin-treated rats urinary glucose loss was $23 \pm 5,25 \pm 3$ and $26 \pm 3 \mu \mathrm{mol} \cdot \mathrm{kg}^{-1} \cdot \mathrm{min}^{-1}$ in the basal, low-dose and high-dose clamp studies, respectively.

The basal plasma glucose, plasma insulin and whole body glucose kinetic data are shown in Figure 1 . Under basal conditions plasma glucose levels were $39 \%$ and $38 \%$ lower in the pregnant and phlorizin-treated rats, respectively, compared to the control rats. The basal insulin levels were correspondingly $43 \%$ lower in the phlorizin-treated compared to the control rats, but were not different between the pregnant and the control rats. The basal HGP rates were $21 \%$ and $26 \%$ higher in the pregnant and phlorizin-treated rats, respectively, compared to the control rats. Ru rates were $21 \%$ higher in the pregnant (includes uptake into the feto-placental unit) compared to the control rats $(p<0.05)$, and $41 \%$ lower in the phlorizin-treated (excludes urinary glucose loss) compared to the control rats (N.S. $p=0.1$ ) (data not shown). Plasma GCR rates were 109\% and $104 \%$ higher in the pregnant and phlorizin-treat- ed rats, respectively, compared to the control rats. $\mathrm{Ba}$ sal glucose uptake index results are shown in Figure 2. Brain glucose uptake indices were not significantly different between groups. Basal glucose uptake indices in all other tissues tended to be lower in the pregnant and phlorizin-treated rats compared to the control rats. Of particular note, the glucose uptake indices in brown adipose tissue were $91 \%$ and $93 \%$ lower and in heart were $81 \%$ and $88 \%$ lower in the pregnant and phlorizin-treated rats, respectively, compared to the control rats. In the pregnant rats, the basal glucose uptake indices of the placenta and fetus (Table 2) were $391 \%$ and $358 \%$ greater, respectively, compared to the average basal glucose uptake index of all the maternal tissues studies, excluding brain.

The low-dose clamp and high-dose clamp plasma glucose, plasma insulin and whole body glucose kinetic results are shown in Table 3. Similar levels of glycaemia and hyperinsulinaemia were achieved between the groups in both the low-dose and high-dose clamp studies. Hyperinsulinaemia suppressed HGP from basal levels in the pregnant rats by $32 \%$ in the low-dose clamp $(p<0.05)$ and by $27 \%$ in the highdose clamp (N.S. $p=0.09$ ) studies and failed to suppress HGP with either insulin dose in the control or phlorizin-treated rats. Rd and plasma GCR were not significantly different between groups at both insulin doses. $\mathrm{Ru}$ was $29 \%$ lower in the phlorizin-treated compared to the control rats $(p<0.001)$ during the low-dose clamp studies (data not shown). The clamp glucose uptake index results are shown in Table 4. As expected brain glucose uptake indices did not respond to hyperinsulinaemia and there remained no differences between groups. Brown adipose tissue 
$\mathbf{A}$

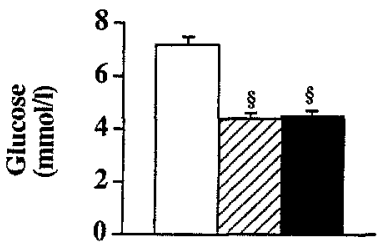

B
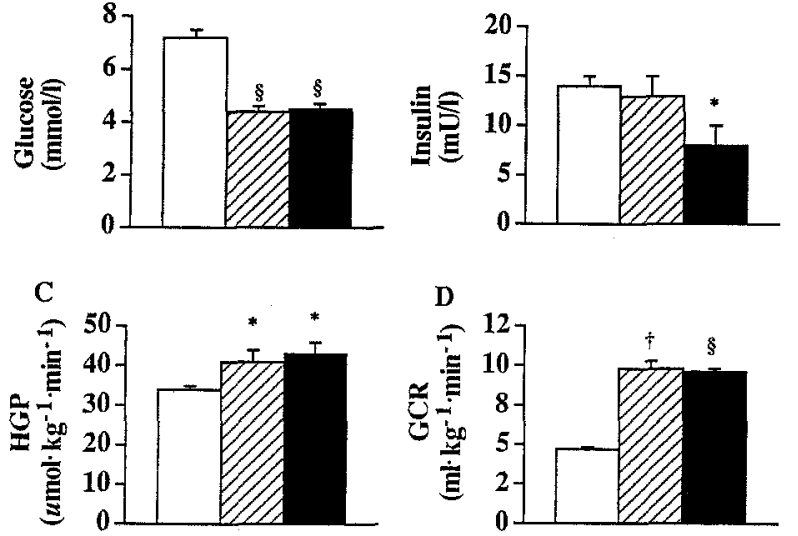

Fig. 1. (A, B, C, D) Basal (A) plasma glucose concentrations, (B) plasma insulin concentrations, (C) hepatic glucose production rates (HGP) and (D) plasma glucose clearance rates (GCR) in control $(n=9) \square$, pregnant $(n=7) \square$ and phlorizin-treated $(n=5) \square$ rats. $* p<0.05$ vs control rats, $\dagger p<0.001$ vs control rats, $\S p<0.0001$ vs control rats

and heart glucose uptake indices greatly increased in response to hyperinsulinaemia in all groups and there were no differences between groups in the high-dose clamp study. Glucose uptake indices in red gastrocnemius and red quadriceps muscles were $55 \%$ and $52 \%$ lower in the pregnant rats, and $42 \%$ and $55 \%$ lower in the phlorizin-treated rats, respectively, in the low-dose clamp study, and $36 \%$ and $25 \%$ lower in the pregnant rats, and $19 \%$ and $22 \%$ lower in the phlorizin-treated rats, respectively, in the high-dose clamp study compared to the control rats. Similar trends were observed in the other skeletal muscles but to a lesser degree. No significant differences between groups were seen in the response of white adipose tissue to insulin. The glucose uptake indices of the placenta (Table 2 ) were $60 \%$ and $57 \%$ higher in the low-dose clamp $(p<0.05)$ and highdose clamp (N.S.) studies, respectively, compared to the basal studies. The glucose uptake indices of the fetus (Table 2) were $29 \%$ and $27 \%$ higher in the low-dose clamp (N.S.) and high-dose clamp studies (N.S.) compared to basal studies.

The serum NEFA level results are shown in Table 5. NEFA levels were $33 \%$ higher in the pregnant rats compared to the control rats basally and remained significantly higher compared to the control rats at $20 \mathrm{~min}$, but not at $50 \mathrm{~min}$, in both the low-dose and high-dose clamp studies. There were no differences in NEFA levels basally or during the clamp studies between the phlorizin-treated and control rats.

\section{Discussion}

It is generally believed that maternal metabolic adaptation to late pregnancy is predominantly mediated by gestational hormones. In this paper we present evi-
A

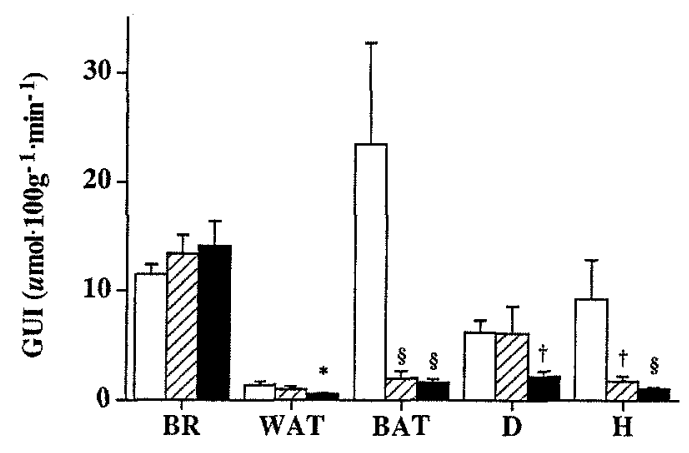

$\mathbf{B}$

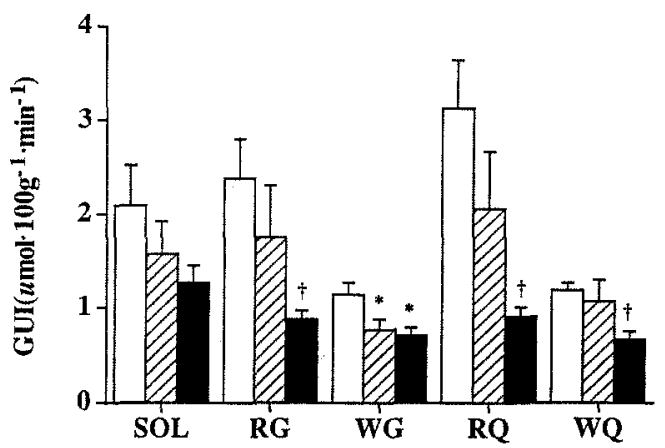

Fig. 2. (A, B) Basal peripheral tissue glucose uptake index measurements (GUI) in (A) brain (BR), white adipose tissue (WAT), brown adipose tissue (BAT), diaphragm (D), heart $(\mathrm{H})$; and in (B) soleus (SOL), red gastrocnemius (RG), white gastrocnemius (WG), red quadriceps (RQ) and white quadriceps (WQ) muscles in control $(n=9) \square$, pregnant $(n=6) \square$ and phlorizin treated $(n=4) \square$ rats. $* p<0.05$ vs control rats, $\dagger p<0.01$ vs control rats, $\S p<0.001$ vs control rats

Table 2. Tissue glucose utilisation index measurements (GUI) of placenta and fetus during basal and low-dose (LDC) and high-dose (HDC) hyperinsulinaemic euglycaemic clamp studies in pregnant rats

\begin{tabular}{lccr}
\hline $\begin{array}{l}\text { GUI } \\
\left(\mu \mathrm{mol} \cdot 100 \mathrm{~g}^{-1} .\right. \\
\left.\mathrm{min}^{-1}\right)\end{array}$ & Basal $(n=6)$ & LDC $(n=8)$ & \multicolumn{1}{l}{$\begin{array}{l}\text { HDC } \\
(n=7)\end{array}$} \\
\hline Placenta & $7.9 \pm 1.1$ & $12.5 \pm 1.6^{\mathrm{a}}$ & $12.3 \pm 2.4$ \\
Fetus & $7.2 \pm 1.0$ & $9.4 \pm 0.7$ & $9.2 \pm 1.0$ \\
\hline
\end{tabular}

Values are means \pm SEM. ${ }^{a} p<0.05$ vs basal

dence firstly, that a feto-placental glucose steal phenomenon operates in late pregnancy, and secondly, that this phenomenon has major influences, independently from the effects of gestational hormones, on the maternal metabolic milieu.

That a feto-placental glucose steal operates in pregnancy is shown in the basal glucose kinetic data. Despite the observed increased basal HGP and peripheral glucose disappearance in pregnancy, glucose uptake into most maternal tissues was reduced. The increased glucose flux must therefore have gone to the feto-placental unit. This is confirmed by the fact 
Table 3. Plasma glucose and insulin levels, HGP, Rd and rates of plasma glucose clearance (GCR) during the low-dose clamp (LDC) and high-dose clamp (HDC) studies in control, pregnant and phlorizin-treated rats

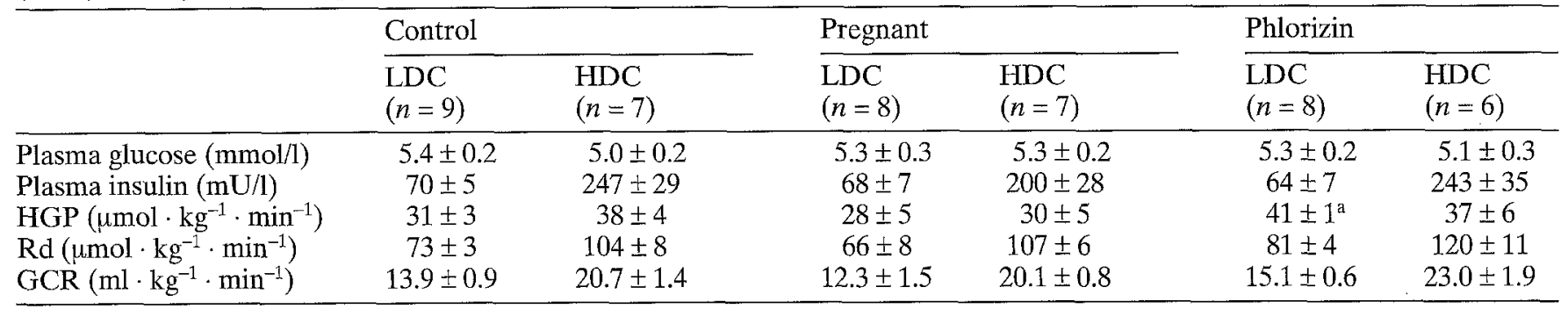

Values are means \pm SEM. ${ }^{a} p<0.01$ vs control LDC

Table 4. Peripheral tissue glucose utilisation index measurements (GUI) during the low-dose (LDC) and high-dose (HDC) clamp studies in control, pregnant and phlorizin-treated rats

\begin{tabular}{|c|c|c|c|c|c|c|}
\hline \multirow{2}{*}{$\begin{array}{l}\text { GUI } \\
\left(\mu \mathrm{mol} \cdot 100 \mathrm{~g}^{-1} \cdot \mathrm{min}^{-1}\right)\end{array}$} & \multicolumn{2}{|l|}{ Control } & \multicolumn{2}{|l|}{ Pregnant } & \multicolumn{2}{|l|}{ Phlorizin } \\
\hline & $\overline{\operatorname{LDC}(n=9)}$ & $\operatorname{HDC}(n=7)$ & $\overline{\operatorname{LDC}(n=8)}$ & $\operatorname{HDC}(n=7)$ & $\mathrm{LDC}(n=8)$ & $\operatorname{HDC}(n=6)$ \\
\hline Brain & $14.8 \pm 1.6$ & $15.5 \pm 1.4$ & $14.5 \pm 2.0$ & $13.1 \pm 0.9$ & $16.3 \pm 2.0$ & $12.5 \pm 1.4$ \\
\hline Brown adipose tissue & $69 \pm 10$ & $60 \pm 8$ & $43 \pm 8$ & $62 \pm 6$ & $72 \pm 10$ & $87 \pm 15$ \\
\hline Diaphragm & $18 \pm 2$ & $32 \pm 1$ & $20 \pm 3$ & $29 \pm 1^{\mathrm{d}}$ & $16 \pm 2$ & $30 \pm 2$ \\
\hline Heart & $42 \pm 4$ & $45 \pm 3$ & $37 \pm 9$ & $46 \pm 6$ & $28 \pm 5^{\mathrm{a}}$ & $53 \pm 4$ \\
\hline White gastrocnemius & $2.4 \pm 0.4$ & $6.2 \pm 0.6$ & $1.4 \pm 0.1$ & $3.7 \pm 0.4^{\mathrm{e}}$ & $1.9 \pm 0.2$ & $4.6 \pm 0.4$ \\
\hline Red quadriceps & $8.4 \pm 0.8$ & $14.0 \pm 0.4$ & $4.0 \pm 0.3^{c}$ & $11.0 \pm 1.0^{\mathrm{d}}$ & $5.2 \pm 0.6^{b}$ & $10.9 \pm 0.5^{\mathrm{e}}$ \\
\hline White quadriceps & $3.8 \pm 0.6$ & $8.0 \pm 0.2$ & $3.4 \pm 0.6$ & $7.3 \pm 0.6$ & $3.2 \pm 0.1$ & $6.6 \pm 0.8$ \\
\hline
\end{tabular}

Values are means \pm SEM. ${ }^{a} p<0.05,{ }^{b} p<0.01,{ }^{c} p<0.001$ vs control LDC; ${ }^{d} p<0.05,{ }^{\mathrm{e}} p<0.01$ vs control HDC

that the glucose uptake indices of the placenta and fetus were considerably higher than those of most maternal tissues. Clearly there is preferential feto-placental glucose uptake with resultant glucose deprivation of maternal tissues.

The overall pattern of basal whole body and individual tissue glucose kinetics in the pregnant rats was closely mimicked by the phlorizin-treated rats. Basal HGP was elevated while basal glycaemia was lower in both compared to the control rats. This relative hypoglycaemia was due to an increased rate of plasma glucose clearance in both. Basal glucose uptake index measurements were markedly reduced in heart and brown adipose tissue in both the pregnant and phlorizin-treated compared to control rats. Skeletal muscle glucose uptake indices basally were also reduced in the phlorizin-treated compared to control rats, as was the trend in the pregnant rats. These results indicate that a glucose steal, as was produced in the phlorizin-treated rats, can independently reproduce most of the characteristics of basal glucose metabolism of late pregnancy. The fasting plasma insulin levels were appropriately suppressed in response to the hypoglycaemia in the phlorizin-treated rats, but this did not occur in the pregnant rats. This difference between the phlorizin-treated and pregnant rats was most probably due to the trophic effects of gestational hormones on the pancreatic islet beta cell in the pregnant rats. This raised "constitutive" insulin
Table 5. Serum NEFA during basal and low and high-dose hyperinsulinaemic euglycaemic clamp studies in control, pregnant and phlorizin-treated rats

\begin{tabular}{llll}
\hline NEFA (mmol/1) & Control & Pregnant & Phlorizin \\
\hline Basal & $0.97 \pm 0.07$ & $1.29 \pm 0.10^{\mathrm{a}}$ & $0.90 \pm 0.13$ \\
Low-dose clamp & & & \\
$20 \mathrm{~min}$ & $0.45 \pm 0.08$ & $0.82 \pm 0.14^{\mathrm{a}}$ & $0.51 \pm 0.04$ \\
$50 \mathrm{~min}$ & $0.41 \pm 0.06$ & $0.62 \pm 0.10$ & $0.45 \pm 0.04$ \\
High-dose clamp & & & \\
$20 \mathrm{~min}$ & $0.36 \pm 0.02$ & $0.61 \pm 0.08^{\mathrm{a}}$ & $0.40 \pm 0.04$ \\
$50 \mathrm{~min}$ & $0.28 \pm 0.04$ & $0.42 \pm 0.06$ & $0.34 \pm 0.06$ \\
\hline
\end{tabular}

Values are means \pm SEM of six to nine rats in each group. ${ }^{\mathrm{a}} p<0.05$ vs control

secretion in pregnancy may explain the fasting hypoglycaemia which occurs prior to increases in glucose turnover while the conceptus is relatively small [16].

In the hyperinsulinaemic euglycaemic clamp studies, although there were no significant differences observed in Rd and plasma GCR between groups, impairment of insulin-stimulated glucose uptake into skeletal muscle was observed in both the pregnant and phlorizin-treated compared to control rats. $\mathrm{Ru}$ was also significantly lower in the phlorizin compared to control rats in the low-dose clamp study. Placental glucose uptake was higher in the clamp compared to the basal studies; consistent with there being a placental response to insulin in the rat as sug- 
gested by Leturque [17]. It needs to be considered, however, that some of the increase in placental glucose uptake in the current clamp compared to basal studies may have been due to the $20 \%$ higher glucose levels. These results indicate that in the pregnant rat maternal skeletal muscle is insulin resistant, but whole body glucose assimilation is not impaired. Presumably, the maternal peripheral insulin resistance is a mechanism by which a postprandial glucose load is spared for feto-placental use. The fact that reduced insulin-stimulated glucose uptake was also seen in the skeletal muscles of the phlorizintreated rats suggests that the glucose steal phenomenon is contributive to this process of maternal postprandial glucose sparing.

The basal glucose turnover findings between the control and pregnant rats in this study are consistent with those of previous studies in rats $[16,18]$ and humans $[19,20]$. Our basal glucose uptake index findings are also consistent with those of Holness et al. [21] who convincingly showed, in postabsorptive conscious rats, that glucose uptake into maternal heart and skeletal muscles is diminished during late pregnancy. In addition, we have shown markedly reduced basal glucose uptake into brown adipose tissue in the pregnant compared to virgin rats. There is an important difference, however, between the current hyperinsulinaemic euglycaemic clamp studies and the similar studies performed by Leturque $[17,18]$. We clamped each group at equivalent levels of euglycaemia. Leturque, in contrast, clamped each group according to it's respective fasting glucose level which was $25 \%$ lower in the pregnant compared to the virgin rats. As peripheral glucose uptake [22] and HGP [23] are responsive to the prevailing glucose level, we are more certain that the differences found between the groups in our studies are due to differences in insulin action and not due to differences in glucose availability.

Previous investigators using hyperinsulinaemic euglycaemic clamp techniques in rats [18] and rabbits $[24,25]$ have concluded that maternal metabolic adaptation in pregnancy is associated with hepatic insulin resistance. The validity of these studies needs to be questioned. Firstly, the levels of glycaemia between pregnant and non-pregnant groups were mostly unmatched. Secondly, it has been shown that tracer estimations of HGP during clamp procedures can be underestimated if the glucose infusate is not labelled, as achievement of tracer steady state can be delayed [26]. Furthermore, in contrast to these studies, enhanced $[27,28]$ and unchanged [20] hepatic insulin sensitivity in pregnancy have also been reported. Interestingly in the present study, in which tracer was added to the glucose infusion, HGP was partially suppressed in the pregnant rats only. We suspect that our failure to suppress HGP during the clamp procedures in the control and phlorizin-treated rats was due to the effects of the anaesthesia and surgical procedures as has been shown by Clark et al. [29]. Clearly, further studies investigating the effects of pregnancy on maternal hepatic glucose metabolism need to be performed.

Phlorizin is a potent competitive inhibitor of sodium-dependent glucose transporters and through this action in the proximal renal tubule promotes glycosuria $[14,30]$. It is less clear, however, whether phlorizin effectively competes with glucose for binding to facilitative glucose transporters which are responsible for insulin-dependent and independent glucose transport into most tissues. The results of published in vitro studies, in which moderately high concentrations of phlorizin ( 1 to $5 \mathrm{mmol} / \mathrm{l})$ have been used, suggest that phlorizin does inibit facilitative glucose transport [31-33]; but the inhibition is weak in comparison to the related substance phloretin [33]. Phlorizin, in vivo, has not been shown to impair glucose utilisation $[14,34]$ and actually improves insulin action in diabetic animals; an effect believed to be due to the normalisation of glycaemia secondary to the induced glycosuria [34]. Phlorizin is eliminated from the circulation by active secretion of the parent drug into the renal tubules and by rapid conjugation to phlorizin glucuronide in the liver [35]. It is probable that the concentrations of phlorizin reached in vivo, at the doses used, are very low compared to the concentrations used in the previous in vitro experiments. In the current validation experiments, we acutely infused phlorizin into functionally anephric rats at an equivalent rate to that used in the longer-term study experiments. The acutely infused phlorizin was shown to be biologically active in intact rats as it induced marked glycosuria. In the anephric rats, both basally and under insulin-stimulated conditions, phlorizin did not directly inhibit glucose utilisation by the whole animal or inhibit glucose uptake into individual tissues. We conclude from these validation studies that, at the dose used, phlorizin has no significant direct effect on glucose metabolism via facilitative glucose transporter inhibition. Therefore the metabolic effects caused by phlorizin in the study experiments must be secondary to the glycosuric action of this drug or the "glucose steal".

The mechanisms by which the glucose steal phenomenon might impair glucose uptake into peripheral tissues needs to be considered. Basally, the steal results in hypoglycaemia such that concentration-dependent glucose transport via the facilitative glucose transporters will be reduced. Further to this, the hypoglycaemia will be associated with relative hypoinsulinaemia such that insulin-stimulated glucose transport will also be minimised. The glucose-fatty acid cycle as proposed by Randle et al. [36] and further characterised by others $[37,38]$, in which increased levels of NEFA oxidation are associated with an inhibition 
of glucose transport, could also be involved in impairing glucose uptake during both basal and insulinstimulated conditions. NEFA levels were measured in the present study and were found to be elevated basally in pregnancy but not in the phlorizin-treated rats. It is still possible however, that both NEFA flux and NEFA oxidation rates were elevated in both the pregnant and phlorizin-treated animals.

In conclusion, the feto-placental glucose steal phenomenon, as modelled in this study with phlorizintreated rats, can independently produce all the features of basal glucose kinetics of late pregnancy. It is likely, therefore, that the glucose steal is the predominant factor regulating postabsorptive maternal glucose metabolism at this stage of pregnancy; and that this phenomenon is the major driving force of "accelerated starvation". The glucose steal phenomenon also significantly contributes, late in pregnancy, to the impairment of insulin-stimulated glucose uptake into maternal skeletal muscle.

Acknowledgements. We gratefully acknowledge the excellent technical assistance of Ms. L. Wilson and Ms. S. Fabris. We wish to thank Professor R. Larkins for his support and helpful comments. This work was supported by an Apex/Diabetes Australia Research Grant, a Royal Melbourne Hospital-Victor Hurley Medical Research Grant and a Program Grant from the National Health and Medical Research Council of Australia. Dr. C.J.Nolan is a National Health and Medical Research Council Postgraduate Medical Scholar.

\section{References}

1. Freinkel N (1980) Of pregnancy and progeny. Diabetes 29: 1023-1035

2. Kalkhoff RK, Kissebah AH, Kim H-J (1978) Carbohydrate and lipid metabolism during normal pregnancy: relationship to gestational hormone action. Semin Perinatol 2: 291-307

3. Houssay BA, Foglia VG, Rodrigeuz RR (1954) Production or prevention of some types of experimental diabetes by oestrogens or corticosteroids. Acta Endocrinol 17: 146164

4. Costrini NV, Kalkhoff RK (1971) Relative effects of pregnancy, estradiol and progesterone on plasma insulin and pancreatic islet insulin secretion. J Clin Invest 50: 992-999

5. Aerts L, Van Assche FA, Faure A, Sutter-Dub MT (1980) Effects of treatment with progesterone and oestradiol-17 $\beta$ on the endocrine pancreas in ovariectomised rats: ultrastructural variations in the B cells. J Endocr 84: 317-320

6. Malaisse WJ, Malaisse-Lagae F, Picard C, Flament-Durand $\mathrm{J}$ (1969) Effects of pregnancy and chorionic growth hormone upon insulin secretion. Endocrinology 84: 41-44

7. Kalkhoff RK, Richardson BL, Beck P (1969) Relative effects of pregnancy, human placental lactogen and prednisolone on carbohydrate tolerance in normal and subclinical diabetic subjects. Diabetes 18: 153-163

8. Landgraf RM, Landgraf-Leurs MC, Weissmann A, Horl R, von Werder K, Scriba PC (1977) Prolactin: a diabetogenic hormone. Diabetologia 13: 99-104
9. Sutter-Dub M-T, Dazey B, Vergnaud M-T, Madec A-M (1981) Progesterone and insulin-resistance in the pregnant rat. I. In vivo and in vitro studies. Diabete Metab 7: 97-104

10. Himsworth HP (1935) The dietetic factor determining the glucose tolerance and sensitivity to insulin of healthy men. Clin Sci 2: 67-94

11. Hales CN, Randle PJ (1963) Effects of low-carbohydrate diet and diabetes mellitus on plasma concentrations of glucose, non-esterified fatty acid, and insulin during oral glucose-tolerance tests. Lancet I: 790-794

12. Randle PJ, Newsholme EA, Garland PB (1964) Regulation of glucose uptake by muscle. 8 . Effects of fatty acids, ketone bodies and pyruvate and of alloxan-diabetes and starvation, on the uptake and metabolic fate of glucose in rat heart and diaphragm muscles. Biochem J 93: 652-665

13. Penicaud L, Kande J, Le Magnen J, Girard JR (1985) Insulin action during fasting and refeeding in rat determined by euglycemic clamp. Am J Physiol 249: E514-E518

14. Rossetti L, Smith D, Shulman GI, Papachristou D, DeFronzo RA (1987) Correction of hyperglycemia with phlorizin normalizes tissue sensitivity to insulin in diabetic rats. $\mathrm{J}$ Clin Invest 79: 1510-1515

15. Kraegen EW, James DE, Jenkins AB, Chisholm DJ (1985) Dose-response curves for in vivo insulin sensitivity in individual tissues in rats. Am J Physiol 248: E 353-E362

16. Ogata ES, Metzger BE, Freinkel N (1981) Carbohydrate metabolism in pregnancy XVI: longitudinal estimates of the effects of pregnancy on D- $\left(6^{3} \mathrm{H}\right)$ glucose and D- $\left(6-{ }^{14} \mathrm{C}\right)$ glucose turnovers during fasting in the rat. Metabolism 30: $487-492$

17. Leturque A, Ferre P, Burnol A-F, Kande J, Maulard P, Girard J (1986) Glucose utilization rates and insulin sensitivity in vivo in tissues of virgin and pregnant rats. Diabetes 35: $172-177$

18. Leturque A, Burnol AF, Ferré P, Girard J (1984) Pregnancy-induced insulin resistance in the rat: assessment by glucose clamp technique. Am J Physiol 246: E25-E 31

19. Kalhan SC, Adam PAJ (1980) Quantitative estimation of systemic glucose production in normal and diabetic pregnancy. Diabetes Care 3: 410-415

20. Catalano PM, Tyzbir ED, Wolfe RR, Roman NM, Amini $\mathrm{SB}$, Sims EAH (1992) Longitudinal changes in basal hepatic glucose production and suppression during insulin infusion in normal pregnant women. Am $\mathrm{J}$ Obstet Gynecol 167: 913-919

21. Holness MJ, Changani KK, Sugden MC (1991) Progressive suppression of muscle glucose utilization during pregnancy. Biochem J 280: 549-552

22. Verdonk CA, Rizza RR, Gerich JE (1981) Effects of plasma glucose concentration on glucose utilization and glucose clearance in normal man. Diabetes 30: 535-537

23. Myers SR, Biggers DW, Neal DW, Cherrington AD (1991) Intraportal glucose delivery enhances the effects of hepatic glucose load on net hepatic glucose uptake in vivo. $\mathbf{J}$ Clin Invest 88: 158-167

24. Hauguel S, Gilbert M, Girard J (1987) Pregnancy-induced insulin resistance in liver and skeletal muscles of the conscious rabbit. Am J Physiol 252: E 165-E 169

25. Gilbert M, Pere MC, Baudelin A, Battaglia FC (1991) Role of free fatty acids in hepatic insulin resistance during late pregnancy in conscious rabbits. Am J Physiol 260: E938E945

26. Finegood DT, Bergman RN, Vranic M (1988) Modelling error and apparent isotope discrimination confound estimation of endogenous glucose production during euglycemic glucose clamps. Diabetes 37: 1025-1034 
27. Davidson MB (1984) Insulin resistance of late pregnancy does not include the liver. Metabolism 33: 532-537

28. Hay WW, Lin C-C, Meznarich HK (1988) Effect of high levels of insulin on glucose utilization and glucose production in pregnant and nonpregnant sheep. Proc Soc Exp Biol Med 189: 275-284

29. Clark PW, Jenkins AB, Kraegen EW (1990) Pentobarbital reduces basal liver glucose output and its insulin suppression in rats. Am J Physiol 258: E 701-E 707

30. Vick H, Diedrich DF, Baumann K (1973) Reevaluation of renal tubular glucose transport inhibition by phlorizin analogs. Am J Physiol 224 (3): 552--557

31. Duckworth WC, Peavy DE, Frechette P, Solomon SS (1986) Insulin-stimulated conversion of D- $\left[5^{3} \mathrm{H}\right]$ glucose to ${ }^{3} \mathrm{HOH}$ in the perifused isolated rat adipocyte. Metabolism 35: 913-918

32. Kohn PG, Clausen T (1971) The relationship between the transport of glucose and cations across cell membranes in isolated tissues. VI. The effect of insulin, ouabain, and metabolic inhibitors on the transport of 3-O-methylglucose and glucose in rat soleus muscles. Biochim Biophys Acta 225: 277-290
33. Ibu JO, Short AH (1986) The inhibitory effect of phlorizin and phloretin on hexose transport in the liver. Scand J Gastroenterol 21 [Suppl 124]: 75-81

34. Kahn BB, Shulman GI, DeFronzo RA, Cushman SW, Rossetti L (1991) Normalization of blood glucose in diabetic rats with phlorizin treatment reverses insulin-resistant glucose transport in adipose cells without restoring glucose transporter gene expression. J Clin Invest 87: 561-570

35. Braun W, Whittaker VP, Lotspeich WD (1957) Renal excretion of phlorizin and phlorizin glucuronide. Am J Physiol 190 (3): 563--569

36. Randle PJ, Hales CN, Garland PB, Newsholme EA (1963) The glucose fatty-acid cycle. Its role in insulin sensitivity and the metabolic disturbances of diabetes mellitus. Lancet I: $785-789$

37. Rennie MJ, Holloszy JO (1977) Inhibition of glucose uptake and glycogenolysis by availability of oleate in welloxygenated perfused skeletal muscle. Biochem J 168: 161170

38. Thiébald D, DeFronzo RA, Jacot E et al. (1982) Effect of long chain triglyceride infusion on glucose metabolism in man. Metabolism 31: 1128-1136 